\title{
The Effect of Time Management on the Academic Performance of Students in the Higher Educational Institutions of Islamabad
}

\author{
MUHAMMAD JEHANGIR KHAN \\ Assistant Professor, at Pakistan Institute of Development Economics (PIDE). \\ Email: jehangir@pide.org.pk \\ AQSA ASHRAF \\ MPhil Scholar, at Pakistan Institute of Development Economics (PIDE). \\ Email: aqsaashraf_16@pide.edu.pk
}

AAMIR NADEEM

Associate Professor, at City University of Science \& Technology (CUST), Peshawar.

Email: aamir.nadeem@cusit.edu.pk

\begin{abstract}
This study investigates the effect of students' time management on their academic achievement in the higher education institutions of Islamabad. For this purpose, we collected data from a representative sample of students. We employ Pearsons' correlation and regression analysis to investigate the influencing factors of academic performance. Our results show that students' self-study has significant and positive association with their academic performance, which indicates that academic performance is increases with the increase in self-study hours. On the contrary, disproportionate involvement in social life enjoyment activities are detrimental to higher academic performance. Female students' academic achievement is higher than that of male students. Perhaps, female students are good time managers and spend more time on self-study. For policy purpose, seminars should be arranged to educate students on how best to allocate their time being enrolled for a full-time study.
\end{abstract}

Keywords: Time Management, Academic Achievement, Islamabad.

\section{Introduction}

Managing time being a student is as important as later in life. It is essential for students to manage their time in daily activities (Abban, 2011). Most students run out of time when an assignment is assigned to them and they are not able to finish it before the last date while others have plenty of time as they are trained to manage their time effectively. Efficient time management ${ }^{1}$ always results in contentment and satisfaction in daily life (Mercanlioglu, 2008).

Time management is important in the sense that it teaches people how to manage their lives and time effectively. Aduke (2015) argues that time management is a skill of organizing, planning, arranging and accounting one's time for creating more productivity and efficient work. It depends on priorities how one's

1 Time management is a process of determining objectives, prioritizing and planning to achieve these objectives. Claessens et al. (2007) defines time management as "behaviors that aim at achieving an effective use of time while performing certain goal directed activities". 
allocate and distribute the time between competing demands as we cannot store time for future and it can never be increase or decrease from 24 hours. Besides, Chaturvedi (2016) argues that time allocation; especially for university students is quite essential as it help to enhance their productivity and grades. Generally, students lack good management skills to organize tasks according to their importance, as a result they are unfocussed, uncertain and task averse. Time allocation includes setting goals as Druker (1994) argues that we must know where we spent our time. We need to prioritize our most important projects so that we are able to complete these projects according to their importance. From the perspective of students, effective time management skills lead to higher academic performance ${ }^{2}$.

Furthermore, Aduke (2015) argued that prioritizing tasks can make work and studying more pleasant which reduces inefficiencies, anxiety and stress. Nonis et.al (1998) states that good time management skills reduce worry and stress of students which enhances their productivity and grades. So, learning the art of time management is a necessity. Some people are good time managers but not everyone. We all have to assure good time management skills to be successful not only in student life but as well later in life. According to Claessens et al. (2005) time management is possible thorough performance, ability ${ }^{3}$ and self-motivation ${ }^{4}$. Studies show that academic achievement is influenced by time management. Sevari and Kandy (2011) argue that in spite of knowing the influence of time management on academic achievement, students do not give due importance to this relationship. Grades are mostly determined by the completion of tasks such as assignments and the quality of effort used to complete it. Khanam et al. (2017) states that academic achievement is the outcome of education and it is generally measured by periodic assessment or examinations but there is no common agreement on how it is best tested or which aspects are more important. Owing to the importance of time management this study deals with investigating the relationship of student's time management and academic achievement in the higher educational institutes of Islamabad. The paper is organized as follows; section 2 reviews the relevant literature. Data and methodology are presented in section 3. Section 4 discusses the main findings of the study. Whereas the final section concludes.

\section{Review of Literature}

This section reviews literature on the effect of students' time management on their academic performance. Numerous studies have examined the factors affecting students' academic performance. Considering these theoretical and empirical work few studies focusses on time management and students' academic performance from the perspective of higher institutes in Pakistan. Most of the reviewed studies (below) found that time planning and self-study are the main factors of achieving higher grades. Besides, lecture attendance does get prime place in this discussion. But neither of these studies control for the influence of students' ability, social life enjoyment and subject interest on academic performance. This study specifically fills this gap by focusing on the interviewing the students in the higher education institutions of Islamabad.

Grave (2011) conducted that students' time allocation have positive effect on undergraduate student's grades. Spending sufficient time in studying and working as teacher assistant or tutor have positive effect on their grades. Serving as a teacher assistant and attending all classes needs high level of motivation

${ }^{2}$ Kpolovie et.al (2014) defines academic achievement as an outcome of education. Academic achievement is measured through examinations, such as knowledge which students have learnt in any formal institute. In this study academic achievement refer to the (CGPA) grades of the students.

3 Scheffler (1985) also defines ability as a kind of potential or performance. In this study researcher used the student ability as student potential for performance.

${ }^{4}$ Gottfried et al. (2001) defines motivation is the willingness and contribution of the student to learn and obtain high academic achievement Motivation may be intrinsic motivation or extrinsic motivation. In this study extrinsic motivation is used. Extrinsic motivation refers to behavior that is driven by external rewards such as money, fame, grades, and praise. 
achieved through the role of time allocation. Besides, Ogundipe \& Falade (2014) investigated the influence of student's time allocation and academic achievement while focusing on time consumed on self-study, course attendance, seminars attendance and involvement in group study. Their findings reveal that attending courses, seminars and self-study are positively associated with academic performance.

Miqdadi et al. (2014) investigated the relationship between time management and academic performance of students by considering procrastination, workload pressure, distraction and disorganization as important factors. The study found successful students are good time managers. George et al. (2008) find that among these factors, time management is the most influential factor of academic achievement and significantly correlated with success. Ali et al. (2013) also determined the factors affecting academic performance of students. Students grade is used as dependent variable whereas age, gender, schooling, faculty, tuition trend, daily study hours, parents socio-economic background, medium of schooling, residential area and accommodation trend are used as independent variables. The study found that daily study hours and socioeconomic status have significant relationship with academic performance. Khanam et al. (2017) analyzed the effect of students' time management on their academic achievement. They focus on students short run and long run planning. The study concluded that students with effective time management achieve high grades and those who do not manage their time effectively achieve low grades. Only one third of the students set their plans and works according to their priorities while majority of the students do not plan and always spend their time without planning. Nasrullah and Khan (2015) analyze how effectively students allocate their time for successfully achieving academic standards. Their findings show positive and significant relationship between time management and students' success. Zulauf \& Gortner (2000) conducted a time diary survey at Ohio State University and a designed questionnaire was used to measure individual time management behavior. They concluded that time management behavior has positive relationship with GPA. Rai (2016) found that the ratio of students who finishes their task on time is very low and these students perform very well than those who do not manage their work. Similar findings are reported by Oyuga (2016) orphaned students of secondary schools in Kenya.

Khatib (2014) examined the relationship between time management and perceived stress. The findings of the study showed negative relationship between time management and perceived stress. Female students reported higher time management than male students. Pehlivan (2013) also determined the influence of time management skills on student's grades. The study shows that the students of Karadeniz technical institute have moderate level of time management. With respect to gender variable, females are good time managers, and they have high grades than male students. Bratti and Staffolani (2013) found the impact of lecture attendance and self-study on the academic achievement of undergraduate students. Their results show that only lecture attendance is positively significant with performance of quantitative courses such as mathematics and economics and it becomes insignificant for most other courses. Similar findings are reported by Cyril (2014) and Plant et al. (2005) for Florida State University.

\section{Data and Methodology}

This section provides an overview of sample selection strategy we used to collect data and the estimation technique used for the estimation of our regression equations.

\section{Data}

In order to address the research objective, we used primary data on important variables like; time management, academic achievement and other important influencing factors such as academic motivation, student ability etc. We collected our data through structured questionnaire from the target population of M.Phil. economics students at International Islamic University, Quaid-e-Azam University and Pakistan Institute of Development Economics, Islamabad. The target population was 196 students, in which 80 were students of Quaid-e-Azam University, 86 from International Islamic university and 30 were from Pakistan Institute of Development Economics. 
The sample ${ }^{5}$ consisted of 196 students at these universities. However, only 171 questionnaires were correctly filled and returned. So, the final sample size of this study remains 171 .

\section{Theoretical Framework}

The Production Function Approach (PFA) is commonly used to examine the productivity relationship between students' scores and factors which influence students' score (Gordon, (2007); Tangaraju et al. (2013); Nahar \& Arshad (2014)). We used the PFA to check the influence of time management on the academic achievement of students. Students' academic achievement is the output and time management, students' ability, academic motivation and students' socioeconomic background are the inputs. An expanded educational production function is used as stated below,

$\mathrm{AACH}=\mathrm{F}(\mathrm{TMG}, \mathrm{ABI}, \mathrm{MOT}, \mathrm{SECB})$

Here AACH is the educational achievement, TMG stands for time management, ABI stands for students' ability, MOT represent student's motivation and SECB stands for the socio-economic background of the student. We used Multiple Linear Regression approach to estimate the above production function. Specifically, the multiple linear regression equation is given as;

$A A C H_{i}=\alpha+\beta_{1}(A G)_{i}+\beta_{2}(G E N)_{i}+\beta_{3}(M S T S)_{i}+\beta_{4}(N O C H)_{i}+\beta_{5}(D P L N)_{i}+\beta_{6}(S L S T)_{i}+\beta_{7}(S W G R)_{i}+$ $\beta_{8}(\mathrm{JHOL})_{i}+\beta_{9}(\mathrm{MEDU})_{i}+\beta_{10}(\text { SINT })_{i}+\beta_{11}(\text { SLENJ })_{i}+\beta_{12}(\text { GMAR })_{i}+\beta_{13}(\text { PIDEST })_{i}+\beta_{14}(\text { IIUIST })_{i}+e_{i}$ ..(1)

In equation (1),

AACH is the dependent variable representing the academic performance of students taken as grades (CGPA) of the students. AG is the age of the student in years. GEN is the gender of the student, male takes value 1, otherwise zero. MSTS represents marital status of the student, if person is married take value 1 , otherwise zero. NOCH represents the number of children this person has. DPLN represents day planning, if the person plans his/her day take value 1, otherwise zero. SLST represents self-study, which measure that how much hour's students spent on self-study per week. SWGR represents students' work group, measuring how many hours students spent on study in a group per week. JHOL represents job holder, which measure whether the student is doing a job, if job holder take value 1, otherwise zero.

MEDU and FEDU represents mother and father education, which measure their educational background in number of years. SINT represents subject interest that measure whether the main reason of going to University is the student special interest in the subject. If the person is interested in the subject, takes value one otherwise zero. SLENJ represents social life enjoyment that measure whether student is going to university to enjoy the social life only. If the student is going to university because he/she can enjoy social life take vale 1, otherwise zero. GMAR represents the Gat marks of the students, which measure the student ability we have taken this indicator as student ability in this study. PIDEST is the institutional dummy, which takes value 1 if the student is from PIDE, otherwise zero. IIUIST is the institutional dummy for the students at International Islamic University, if the student from IIUI takes value 1, otherwise zero.

\section{Results and Discussion}

This section reports the main findings of our study. We present the descriptive statistics in the first section. Onwards, we report Pearson correlations and the estimates of our main regression equation in the second section.

\footnotetext{
${ }^{5}$ When population is finite the whole population is considered as sample.
} 


\section{Descriptive Statistics}

Table 1 presents the demographic characteristics of the respondents. Being university students, their average age is 22.1 years. Average monthly income of the respondent's family is Rs. 97701. About 54 percent of the respondents are male. Nearly, 98 percent of the students are unmarried. About 44.4 percent of the students are from the IIU followed by QAU (39.8 percent). The remaining students are from PIDE (15.4 percent in total).

Nearly, 11.1 percent of the students are jobholders. Most of them are working evening shifts in different organizations. Nearly, 55 percent of these students have 'A' grades in their last degree. Whereas 38.6 percent students have 'B' grades. Majority of the respondent's father have government job (47.4 percent), followed by own a business (28.6 percent). Whereas most of the mothers are housewives ( 86 percent). Table 3 indicating the language of the respondents' that majority of the respondents (36.3 percent) speaks Urdu, followed by Pashto (33.3 percent). About (17.0 percent) speaks Punjabi. Whereas the proportion of Balti and Sindhi languages are 5.3 and 4.1 percent, respectively. The lowest percentage is of Kashmiri language (1.8 percent).

Table 1 Demographic Characteristics of the Respondents

\begin{tabular}{|l|c|c|c|c|}
\hline Variables & $\mathrm{N}$ & Min. & Max. & Mean \\
\hline Age & 171 & 20.00 & 25.00 & 22.1579 \\
\hline Household Size & 171 & 3.00 & 20.00 & 7.4327 \\
\hline Family Income (monthly) & 171 & 10000 & 500000 & 97701.75 \\
\hline Gender (male) & 171 & 0 & 1 & 0.544 \\
\hline Marital status (married) & 171 & 0 & 1 & 0.023 \\
\hline Doing job (yes) & 171 & 0 & 1 & 0.111 \\
\hline A & 94 & - & - & 0.55 \\
\hline B & 66 & - & - & 0.386 \\
\hline C & 11 & - & - & 0.064 \\
\hline Fathers' Occupation & & & & 0.123 \\
\hline Private Job & 21 & - & - & 0.474 \\
\hline Government Job & 81 & - & - & 0.287 \\
\hline Own Business & 49 & - & - & 0.064 \\
\hline Agriculture & 11 & - & - & 0.053 \\
\hline Other & 9 & - & - & 0.86 \\
\hline Mothers' Occupation & & & & 0.129 \\
\hline Housewife & 147 & - & - & 0.006 \\
\hline Government Job & 22 & - & - & 0.006 \\
\hline Private Job & 1 & - & - & 0.444 \\
\hline Own Business & 1 & - & - & 0.398 \\
\hline IIU & 76 & 0 & 1 & 0.158 \\
\hline QAU & 27 & 0 & 1 & \\
\hline PIDE & 68 & 0 & 1 & \\
\hline & Source: Based on field survey & \\
\hline & & & \\
\hline
\end{tabular}

Table 2: Language of the Respondents

\begin{tabular}{|l|c|c|}
\hline \multicolumn{1}{|c|}{ Languages } & Frequency & Percent \\
\hline Urdu & 62 & 36.3 \\
\hline Punjabi & 29 & 17.1 \\
\hline Sariki & 4 & 2.3 \\
\hline Sindhi & 7 & 4.1 \\
\hline Pashto & 57 & 33.3 \\
\hline
\end{tabular}




\begin{tabular}{|l|c|c|}
\hline Balti & 9 & 5.3 \\
\hline Kashmiri & 3 & 1.8 \\
\hline Total & 171 & 100.0 \\
\hline
\end{tabular}

Source: Based on field survey

Table 3: Previous Degree Grades by Institution

\begin{tabular}{|c|c|c|c|c|c|c|}
\hline Indicators & \multicolumn{2}{|c|}{ (IIUI) N = 76 } & \multicolumn{2}{c|}{ (QAU) N= 68 } & \multicolumn{2}{c|}{ (PIDE) N= 27 } \\
\hline Grades & $\begin{array}{c}\text { Frequenc } \\
\mathbf{y}\end{array}$ & Percentage & Frequency & Percentage & $\begin{array}{c}\text { Frequenc } \\
\mathbf{y}\end{array}$ & $\begin{array}{c}\text { Percenta } \\
\text { ge }\end{array}$ \\
\hline A & 27 & 35.5 & 52 & 76.5 & 15 & 55.6 \\
\hline B & 40 & 52.6 & 14 & 20.6 & 12 & 44.6 \\
\hline C & 9 & 11.8 & 2 & 2.9 & 0 & 0 \\
\hline
\end{tabular}

Source: Based on field survey

Table 4: Time Management and Academic Performance

\begin{tabular}{|l|c|c|c|c|c|c|c|c|c|}
\hline \multirow{2}{*}{ Indicators } & \multicolumn{3}{|c|}{ IIU } & \multicolumn{3}{c|}{ QAU } & \multicolumn{3}{c|}{ PIDE } \\
\cline { 2 - 10 } & MIN & AVG & MAX & MIN & AVG & MAX & MIN & AVG & MAX \\
\hline Self-study & 0 & 2.28 & 8 & 0 & 2.41 & 10 & 0 & 1.8 & 4 \\
\hline Study groups & 0 & 1.14 & 5 & 0 & .94 & 6 & 0 & 1.29 & 5 \\
\hline OSRA & 0 & 1.49 & 6 & 0 & 1.47 & 6 & 0 & 1.81 & 10 \\
\hline GAT marks & 0 & 3.18 & 6 & 1 & 5.35 & 8 & 1 & 3.74 & 7 \\
\hline CGPA & 2 & 3.18 & 3.90 & 2 & 3.76 & 4 & 2.40 & 3.34 & 3.92 \\
\hline
\end{tabular}

$\mathrm{MIN}=$ minimum $\mathrm{AVG}=$ average $\mathrm{MAX}=$ maximum OSRA $=$ Other Study Related Activities

Table 3 shows the grades of the students, which he/she obtained in their previous degree by institution. Nearly, 76.5 percent of the QAU students have ' $A$ ' grades in their last degree, followed by PIDE (55.6 percent). The lowest proportion is of IIU (35.5 percent).

Table 4 shows that QAU students spend more time on self-study, followed by PIDE. Whereas study in group is more common in PIDE followed by IIU. Other study related activities e.g. participation seminars and conferences are more common in PIDE as compared to QAU and IIU. QAU students are higher achievers in terms of GAT marks, followed by PIDE. Furthermore, students of QAU have higher CGPA, followed by PIDE.

\section{Pearson Correlation}

We also estimated Pearson correlation to check the correlation between academic performance and other variables of interest. Table 5 shows that there is positive and significant relationship between self-study and students' academic achievement, which indicates that self-study enable students to get higher academic performance. The relationship of day planning with academic performance is positive, but other study related activities has negative influence on academic performance. This shows that spending time on other activities, lower academic score. Furthermore, the effect of social life enjoyment on academic performance (CGPA) is negative and significant. Which means that involvement in social activities being a full-time student is detrimental for academic performance. The effect of students' ability is positive but insignificant in our case.

In the above table of correlation family income is positively correlated with academic performance. Father education and mother education also have positive correlation with academic performance. Family income 
is significantly correlated with mother and father education the reason behind is that if both are educated and they may be doing jobs and they will efficiently manage the family income.

Table 5 Pearson Correlations (Academic Performance and other Factors)

\begin{tabular}{|l|c|}
\hline Variables & CGPA \\
\hline Day planning & .014 \\
\hline Other study related activities (OSRA) & -.025 \\
\hline Self-study & $.172^{*}$ \\
\hline Subject interest (SI) & -.108 \\
\hline Useful to the society (USFTS) & .012 \\
\hline No other option (NOP) & -.027 \\
\hline Job prospects (JP) & .050 \\
\hline Social life enjoyment (SLE) & $-.174^{*}$ \\
\hline Social pressure (SP) & -.061 \\
\hline Student ability & .137 \\
\hline Family income & .004 \\
\hline Mother education & .105 \\
\hline Father education & .071 \\
\hline
\end{tabular}

*. Correlation is significant at 0.05 level. **. Correlation is significant at 0.01 level.

\section{Empirical Results}

We estimated equation (1), through OLS while including the influencing factors of student's performance (see Table 6). The students' academic performance (CGPA) is the dependent variable which is explained by a number of independent variables. The results show that the effect of age on CGPA is positive and significant, which indicates that CGPA is increases in the age of the students. The study also found that CGPA is negatively and significantly associated with gender, which indicates that female students have higher CGPA as compared to male students. These results are similar to previous studies. Hadii and Fagroud (2018) observed that, nowadays, female students get higher grades than male students in nearly all disciplines. Sheard (2009) also found that female significantly outperformed their counterparts in academic achievement. Marital status is negatively associated with CGPA, which means if a person is married there are less chances for him to get higher CGPA. Married person is more busy, due to the responsibilities of home activities. However, its estimated effect is statistically insignificant in our case. The estimated coefficient of variable number of children is negative but insignificantly associated with CGPA. The effect of day planning is positive but insignificant. Self-study is positive and significantly associated with CGPA, which indicates that academic performance is increases with the increase in self-study hours. These results conform to the studies by Zulauf and Gortnet (2000) and Mercanoilglu (2010) who found that students' grades are increases in self-study.

Students' work in groups is negatively associated with CGPA, which, indicates that if a student spent time in group work, he has less chances of getting higher CGPA. Job is positive but insignificant associated with GGPA. The effect of parental education is insignificant in our case, as parental education may not matter for increase in students' grades at higher level education (being enrolled for M.Phil. degree). The estimated effect of subject interest is negative and insignificant. Koller et.al (2001) states that subject interest has bidirectional relationship with academic achievement which might help increase motivation that leads to academic success.

The effect of social life enjoyment on the academic performance of students is negative and significant, which means that students' excessive involvement in social life enjoyment activities adversely affecting their grades. Umar et.al (2010) found excessive involvement of students in social enjoyment activities has 
negative effect on their academic performance. But contrary to our results, Haider et.al (2015) found positive and significant relationship between social life enjoyment and academic performance.

Our results also show that GAT marks have positive and significant relationship with CGPA. Variable " GAT marks" is used to measure the students' ability. Our results conform to that of Chemers et al. (2001) that academic ability is significantly and directly related to academic performance. The estimated effect of the institutional dummy for PIDE students positive and statistically significant but the same is not true in case of IIU.

Table 6: The Determinates of Students' Academic Performance (CGPA)

\begin{tabular}{|l|c|c|}
\hline Variables & CGPA & Sig. \\
\hline Constant & 2.243 & .000 \\
\hline Age & .047 & .075 \\
\hline Gender (male) & -.352 & .000 \\
\hline Marital status & -.035 & .928 \\
\hline No. of children & -.198 & .285 \\
\hline Day planning & .065 & .336 \\
\hline Self-study & .050 & .007 \\
\hline Student group work & -.028 & .265 \\
\hline Job holder & .017 & .863 \\
\hline Father Education & -.001 & .911 \\
\hline Mother education & .006 & .270 \\
\hline Subject interest & -.032 & .292 \\
\hline Social life enjoyment & -.043 & .086 \\
\hline Gat_Marks & .044 & .034 \\
\hline PIDEs' Student (YES) & .287 & .005 \\
\hline IIUs' Student (YES) & .086 & .318 \\
\hline Adjusted R Square & \multicolumn{2}{|c|}{} \\
\hline N & \multicolumn{2}{|c|}{0.186} \\
\hline F & 3.584 \\
\hline
\end{tabular}

\section{Conclusion and Recommendations}

This study attempts to investigate the relationship of time management indicators and academic performance CGPA. Female students' academic achievement is higher than that of male students in the higher education institutes of Islamabad. Perhaps, female students are good time managers and spend more time on self-study. The effect of self-study on academic performance is positive and significant, which indicates that academic performance is increases with the increase in self-study hours.

Furthermore, excessive involvement in social life enjoyment activities are detrimental for higher academic performance as variable social life enjoyment is negatively and significantly associated with academic performance (CGPA).

Parents and teachers should monitor and encourage students to avoid participation in social enjoyment activities and focus on necessitating for more involvement in self-study through indulging them in more assignments and tests on weekly basis. Seminars should be arranged to educate the students on how best to allocate their time being enrolled for a full-time study. 


\section{References}

Abban, K. (2011). Understanding the importance of time management to assistant registrar's in the registrars department of the university of education. International Journal of Scienti ic \& Engineering Research, 3(12), 1-16.

Aduke, A. F. (2015). Time Management and Students Academic Performance in Higher Institutions, Nigeria A Case Study of Ekiti State. International Research in Education, 3(2), 1-12.

Ali, S., Haider, Z., Munir, F., Khan, H., \& Ahmed, A. (2013). Factors contributing to the students academic performance: A case study of Islamia University Sub-Campus. American Journal of Educational Research, 1(8), 283-289.

Al Khatib, A. S. (2014). Time management and its relation to students' stress, gender and academic achievement among sample of students at Al Ain University of science and technology, UAE. International Journal of Business and Social Research, 4(5), 47-58.

Bratti, M., \& Staffolani, S. (2013). Student time allocation and educational production functions. Annals of Economics and Statistics/Annales D'économie Et De Statistique, 103-140.

Carroll, J. B. (1993). Human cognitive abilities: A survey of factor-analytic studies. Cambridge University Press.

Cyril, A. V. (2014). Time Management and Academic Achievement of Higher Secondary Students. $i$ Manager's Journal on School Educational Technology, 10(3), 38.

Chaturvedi, A.(2016). Impact of Time Management on the Academic Growth of Students in Universities, Nigeria. Intl J Engg Sci Adv Research, 2(4), 7-9.

Claessens, B. J., Van Eerde, W., Rutte, C. G., \& Roe, R. A. (2007). A review of the time management literature. Personnel review, 36(2), 255-276.

Drucker, P.F. (1994). The Effective Executive. New York: Harper and Row.

Etikan, I. (2016). Comparison of Convenience Sampling and Purposive Sampling. American Journal of Theoretical and Applied Statistics, 5(1), 1.

George, D., Dixon, S., Stansal, E., Gelb, S. L., \& Pheri, T. (2008). Time diary and questionnaire assessment of factors associated with academic and personal success among university undergraduates. Journal of American College Health, 56(6), 706-715.

Gordon, W. (2007). The production function approach to calculating potential growth and output gaps. EU Commissions, 12, 132-150.

Gottfried, A. E., Fleming, J. S., \& Gottfried, A. W. (2001). Continuity of academic intrinsic motivation from childhood through late adolescence: A longitudinal study. Journal of educational psychology, 93(1), 3 .

Grave, B. S. (2011). The effect of student time allocation on academic achievement. Education Economics, 19(3), 291-310.

Haider, S. A., Qureshi, M. M., Pirzada, S. S., \& Shahzadi, I. (2015). A Study of Student's Motivation and its Relationship with their Academic Performance. Journal of Resources Development and Management, 8, 9-17.

Hdii, S., \& Fagroud, M. (2018). The effect of gender on university students' school performance: the case of the National School of Agriculture in Meknes, Morocco. Kultūra ir visuomene: socialiniu tyrimu žurnalas, 9 (1), 67-78.

Kaushar, M. (2013). Study of impact of time management on academic performance of college students. Journal of Business and Management (IOSR-JBM), 9(6), 59-60.

Karim, S., \& Kandy, M. (2011). Time management skills impact on self-efficacy and academic performance. Journal of American Science, 7(12), 720-726.

Khanam, N., Sahu, T., Rao, E., Kar, S., \& Quazi, S. Z. (2017). A study on university student's time management and academic achievement. International Journal Of Community Medicine And Public Health, 4(12), 4761-4765.

Kothari, C. R. (2004). Research methodology: Methods and techniques. New Age International.

Koller, O., Baumert, J., \& Schnabel, K. (2001). Does interest matter? The relationship between academic interest and achievement in mathematics. Journal for Research in Mathematics Education, 448-470. 
Kpolovie, P. J., Joe, A. I., \& Okoto, T. (2014). Academic achievement prediction: Role of interest in learning and attitude towards school. International Journal of Humanities

Lakein, A. (1973). How to get control of your time and your life. New York: New American Library.

Mercanlioglu, Ç. (2010). The relationship of time management to academic performance of master level students. International Journal of Business ands Management Studies, 2(1), 25-36.

Miqdadi, F., Almomani, A., Masharqa, M., \& Elmousel, N. (2014). The Relationship between Time Management and the Academic Performance of Students from the Petroleum Institute in Abu Dhabi, the UAE. Paper presented at the ASEE 2014 Zone I Conference.

Misra, R., \& McKean, M. (2000). College students' academic stress and its relation to their anxiety, time management, and leisure satisfaction. American journal of Health studies, 16(1), 41.

Nahar, M., \& Arshad, M. (2014). An Estimation of Educational Production Function: The Case of Tasmanian Public Schools, (November 2010).

Nasrullah, S., \& Khan, M. S. (2015). The Impact of Time Management on the Students' Academic Achievements. Journal of Literature, Languages and Linguitsics.

Nonis, S. A., Hudson, G. I., Logan, L. B., \& Ford, C. W. (1998). Influence Of Perceived Control Over Time On College Students'stress And Stress-Related Outcomes. Research in Higher Education, 39(5), 587-605.

Ogundipe, M. A., \& Falade, O. A. (2014). Student-Teacher Perception of Time Allocation and Academic Achievement in Tai Solarin University of Education. International Journal of Learning and Development, 4(1), 65-70.

Orpen, C. (1994). The effect of time-management training on employee attitudes and behavior: A field experiment. The Journal of psychology, 128(4), 393-396.

Oyuga, P. A., Raburu, P., \& Aloka, P. J. (2016). Relationship between Time Management and Academic Performance among Orphaned Secondary School Students of Kenya. International Journal of Applied Psychology, 6(6), 171-178.

Pehlivan, A. (2013). The effect of the time management skills of students taking a financial accounting course on their course grades and grade point averages. International Journal of Business and Social Science, 4(5).

Rai, A. (2016). A study of impact of Time Management on Academic Performance of Students Studying in School. Indian Journal of Research.

Sarantakos, S. (1993). Social Research Australia: MacMillan Education Australia PTY Ltd.

Scheffler, I. (1985). Of Human Potential. An Essay in the Philosophy of Education. Routledge \& Kegan Paul Inc., 29 West 35th Street, New York, NY 10001.

Sheard, M. (2009). Hardiness commitment, gender, and age differentiate university academic performance. British Journal of Educational Psychology, 79(1), 189-204.

Singh, Y. K. (2006). Fundamental of research methodology and statistics. New Age International.

Tangaraju, K., Ho, S. C., Tan, L. K., Tan, S. Y., \& Tan, W. M. (2013). Analysis of factors influencing the academic performance of undergraduates in Kampar (Doctoral dissertation, UTAR).

Thrash, T. M., \& Elliot, A. J. (2001). Delimiting and integrating achievement motive and goal constructs. In Trends and prospects in motivation research (pp. 3-21). Springer, Dordrecht.

Umar, S. S., Shaib, I. O., Aituisi, N., Yakubu, N. A., \& Bada, O. (2010). The effect of social factors on students' academic performance in Nigerian tertiary institutions. Library philosophy and practice.

Zulauf, C. R. \& Gortnet, A. K. (2000). Use of time and academic performance of college students does studying matter? American Agricultural Economics Association, 3(2), 8-11. 